\title{
Efekty działalności innowacyjnej w Polsce i w województwie lubelskim w latach 2016-2018
}

\author{
The effects of innovative activities in Poland and in the Lubelskie
} Voivodeship in 2016-2018

\section{Wprowadzenie}

W gospodarce rynkowej kluczowym elementem konkurencyjności i rozwoju każdego rodzaju przedsiębiorstwa, bez względu na jego wielkość i branżę, w której działa, jest zdolność do szybkiego i skutecznego wdrażania innowacji. Utrzymanie i poprawa pozycji konkurencyjnej, osiągniętej przez podmioty gospodarcze, wymagają ciągłego prowadzenia efektywnej działalności innowacyjnej. Celem przedsiębiorstwa realizującego taką aktywność powinno być nie tylko dążenie do podniesienia poziomu innowacyjności, ale i do uzyskania dzięki temu odpowiedniej efektywności (Matras-Bolibok, 2009). W związku z tym, że innowacyjność jest zjawiskiem złożonym, występują problemy z pomiarem zarówno jej samej, jak i jej efektów. W artykule podjęto próbę oceny efektów działalności innowacyjnej przedsiębiorstw z Polski i z województwa lubelskiego na podstawie danych zaczerpniętych z Banku Danych Lokalnych GUS. Obserwacją objęto okres od 2016 do 2018 r. Analiza efektów działalności innowacyjnej przedsiębiorstw województwa lubelskiego i całego kraju opierać się będzie na zastosowaniu dostępnych wskaźników dotyczących potencjału innowacyjnego firm zarówno w zakresie ich bieżącej aktywności, jak i dynamice zmian. Celem artykułu jest również przedstawienie i omówienie najważniejszych problemów związanych z pomiarem efektów tego rodzaju aktywności podmiotów gospodarczych. W pierwszej części objaśniono istotę działalności innowacyjnej przedsiębiorstw, jej cele oraz efekty, które może ona generować w różnych obszarach funkcjonowania przedsiębiorstwa. W drugiej części 
omówiono problemy związane z pomiarem efektów aktywności innowacyjnej. Końcowy etap pracy zawiera analizę efektów działalności innowacyjnej przedsiębiorstw przemysłowych i usługowych w Polsce i województwie lubelskim w latach 2016-2018.

\section{Działalność innowacyjna i jej efekty}

Zgodnie ze standardem wprowadzonym przez Organizację Współpracy Gospodarczej i Rozwoju (OECD) innowacja to wdrożenie w praktyce gospodarczej nowego albo znacząco udoskonalonego produktu, usługi lub procesu, w tym także wdrożenie nowej metody marketingowej lub organizacyjnej redefiniującej sposób pracy lub relacje firmy z otoczeniem (OECD, 2008). Zgodnie z tą definicją nie jest innowacją samo wynalezienie nowego produktu czy procesu lub organizacji, nie jest nią również prowadzenie badań w tym zakresie; dopiero wprowadzenie do działalności biznesowej nowych rozwiązań oznacza innowację (Chabiera, 2013). Innowacje warunkujące rozwój przedsiębiorstwa są rezultatem prowadzonej przez to przedsiębiorstwo działalności innowacyjnej. Innowacja jest efektem tworzenia nowych wartości (Stanisławski, 2017). Efektywna aktywność innowacyjna zmierza do wprowadzenia na rynek nowych produktów i usług w celu zaspokojenia stale zmieniających się potrzeb klientów i jest warunkiem osiągania przez przedsiębiorstwa sukcesu rynkowego (Matras-Bolibok, 2009).

Innowacje mają na celu poprawę efektywności funkcjonowania przedsiębiorstwa poprzez zyskanie przewagi konkurencyjnej lub po prostu przez utrzymanie poziomu konkurencyjności (OECD, 2008). Aktywność przedsiębiorstwa w sferze innowacyjności jest zasadnicza dla jego trwania i konstruktywnego rozwoju. Definicja GUS określa działalność innowacyjną jako wszelkie działania rozwojowe, finansowe i komercyjne podejmowane przez przedsiębiorstwo, mające na celu doprowadzenie do powstania innowacji dla przedsiębiorstwa. Działalność innowacyjna obejmuje więc działalność badawczą i rozwojową (B+R), niezależnie od jej celu, prace inżynieryjne, projektowe i inne prace twórcze, marketing i działania dotyczące wartości marki, działalność związaną z własnością intelektualną, szkolenie pracowników, rozwój oprogramowania i działalność związaną z bazami danych, z nabywaniem lub dzierżawą rzeczowych aktywów trwałych, jak i działalność w zakresie zarządzania innowacjami. Działalność innowacyjna może zostać zakończona innowacją, być w toku, odłożona w czasie lub zaniechana (GUS, Słownik pojęć). Jednakże bez względu na rodzaj tychże 
działań, działalność ta powinna przyczyniać się do poprawy efektywności funkcjonowania organizacji.

Prowadzenie tej aktywności wiąże się z koniecznością ponoszenia wydatków związanych z kreowaniem czy też nabywaniem innowacji oraz z ich wdrażaniem w przedsiębiorstwie. Ponosząc nakłady na działalność innowacyjną, właściciele przedsiębiorstw oczekują uzyskania pewnych korzyści z wdrożonych innowacji (Zakrzewska, 2014). Ogólnie rzecz biorąc, korzyści działalności innowacyjnej obejmują wszystkie te efekty, które wiążą się z wprowadzeniem innowacji technologicznych - w postaci nowych produktów i/lub usług bądź też korzyści z nowych sposobów wytwarzania - oraz organizacyjnych - jako poprawę funkcjonowania podmiotu. Są to zarówno zmiany o charakterze ekonomicznym, jak i pozaekonomicznym, które zachodzą w obrębie przedsiębiorstwa oraz w jego otoczeniu. Mogą występować w postaci wartości, ilości lub jakości (Białoń, 2010).

Aktywność innowacyjna może przynosić założone efekty lub inne - dodatkowe w porównaniu z tym, co pierwotnie było powodem ich wprowadzenia. Efekty odnoszą się do faktycznie uzyskanych skutków innowacji, do realizacji założonych celów. W tabeli 1 przedstawiono wykaz efektów możliwych do uzyskania w wyniku prowadzonej działalności. W przypadku innowacji produktowej firma może uzyskać przewagę konkurencyjną, wprowadzając nowy produkt, co pozwala jej na zwiększenie popytu i marż. Nowy produkt lub proces może stać się dla innowatora źródłem przewagi rynkowej (OECD, 2008). Bezpośrednim efektem działań innowacyjnych są bowiem często produkty (niekiedy niematerialne), które tworzą potencjał możliwy do przekształcenia w przychody i zyski (Łada, Orchel-Szeląg, 2015).

Tabela 1. Efekty innowacji w różnych obszarach oddziaływania w przedsiębiorstwie

\begin{tabular}{|l|l|l|l|}
\hline \multicolumn{1}{|c|}{$\begin{array}{c}\text { Konkurencja, } \\
\text { popyt i rynki }\end{array}$} & Produkcja i dostawa & \multicolumn{1}{|c|}{$\begin{array}{c}\text { Organizacja } \\
\text { miejsca pracy }\end{array}$} & \multicolumn{1}{c|}{ Inne } \\
\hline $\begin{array}{l}\text { Stworzenie produktów } \\
\text { przyjaznych dla środo- } \\
\text { wiska naturalnego }\end{array}$ & $\begin{array}{l}\text { Zwiększenie efektywności } \\
\text { lub szybkości zapewnia- } \\
\text { nia bądź dostarczania } \\
\text { wyrobów i usług }\end{array}$ & $\begin{array}{l}\text { Zwiększenie zakresu } \\
\text { udostępniania lub } \\
\text { transferu wiedzy } \\
\text { w kontaktach z innymi } \\
\text { podmiotami }\end{array}$ & $\begin{array}{l}\text { Ograniczenie skut- } \\
\text { ków dla środowiska } \\
\text { naturalnego lub } \\
\text { poprawa zdrowotno- } \\
\text { ści bądź bezpieczen- } \\
\text { stwa }\end{array}$ \\
\hline $\begin{array}{l}\text { Poszerzenie oferty } \\
\text { wyrobów i usług }\end{array}$ & $\begin{array}{l}\text { Zwiększenie elastyczności } \\
\text { produkcji lub świadcze- } \\
\text { nia usług }\end{array}$ & $\begin{array}{l}\text { Ooprawa komunikacji } \\
\text { i interakcji między } \\
\text { różnymi pionami } \\
\text { w firmie }\end{array}$ & $\begin{array}{l}\text { Wypełnienie wymo- } \\
\text { gów regulacyjnych }\end{array}$ \\
\hline
\end{tabular}


12 | Przegląd Prawno-Ekonomiczny

\begin{tabular}{|c|c|c|}
\hline $\begin{array}{l}\text { Zwiększenie lub } \\
\text { zachowanie udziału } \\
\text { w rynku }\end{array}$ & $\begin{array}{l}\text { Obniżenie kosztów ope- } \\
\text { racyjnych związanych ze } \\
\text { świadczeniem usług }\end{array}$ & $\begin{array}{l}\text { Zwiększenie zdolności } \\
\text { dostosowywania się do } \\
\text { wymogów klientów }\end{array}$ \\
\hline $\begin{array}{l}\text { Zastąpienie produktów } \\
\text { wycofanych z rynku }\end{array}$ & $\begin{array}{l}\text { Obniżenie jednostkowych } \\
\text { kosztów pracy }\end{array}$ & $\begin{array}{l}\text { Wzmocnienie relacji } \\
\text { z klientami }\end{array}$ \\
\hline $\begin{array}{l}\text { Wejście na nowe rynki } \\
\text { zbytu }\end{array}$ & $\begin{array}{l}\text { Obniżenie zużycia mate- } \\
\text { riałów i energii }\end{array}$ & $\begin{array}{l}\text { Poprawa warunków } \\
\text { pracy }\end{array}$ \\
\hline $\begin{array}{l}\text { Zwiększenie widocz- } \\
\text { ności lub ekspozycji } \\
\text { produktów }\end{array}$ & $\begin{array}{l}\text { Obniżenie kosztów } \\
\text { projektowania produktów }\end{array}$ & \\
\hline \multirow{5}{*}{$\begin{array}{l}\text { Skrócenie czasu } \\
\text { reakcji na potrzeby } \\
\text { klientów }\end{array}$} & $\begin{array}{l}\text { Podniesienie jakości } \\
\text { wyrobów i usług }\end{array}$ & \\
\hline & $\begin{array}{l}\text { Osiągnięcie sektorowych } \\
\text { standardów technicznych }\end{array}$ & \\
\hline & $\begin{array}{l}\text { Zwiększenie mocy } \\
\text { produkcyjnych lub } \\
\text { usługowych }\end{array}$ & \\
\hline & $\begin{array}{l}\text { Skrócenie cyklu produk- } \\
\text { cyjnego }\end{array}$ & \\
\hline & $\begin{array}{l}\text { Poprawa potencjału } \\
\text { informatycznego }\end{array}$ & \\
\hline
\end{tabular}

Źródło: OECD, 2008, s. 21-22; 111-113.

Efekty innowacji produktowych można mierzyć odsetkiem sprzedaży z tytułu nowych lub udoskonalonych produktów (OECD, 2008). Przedsiębiorstwo, które jako pierwsze wprowadza do praktycznego zastosowania innowację produktową, osiąga bezpośredni efekt w postaci zysku monopolowego. Jego wielkość zależy od stopnia innowacyjności produktu, stąd w przypadku innowacji obejmujących niewielkie zmiany zyski te są odpowiednio niższe niż w przypadku wprowadzenia zupełnie nowego rozwiązania. Po pewnym czasie, $w$ drodze dyfuzji, innowacje przynoszą kolejne pozytywne efekty w innych firmach (Karmańska, 2007). Podniesienie efektywności funkcjonowania firmy dzięki wprowadzonym innowacjom może nastąpić poprzez zwiększenie popytu lub redukcję kosztów. Efekty innowacji w postaci podniesienia jakości produktów, zaoferowania nowych produktów czy też zyskania nowych rynków lub grup klientów przesuwają krzywą popytu na produkty firmy. Przedsiębiorstwa mogą również zwiększyć popyt poprzez dywersyfikację produktów, wejście na nowe rynki oraz kształtowanie popytu na istniejące produkty. Natomiast efekty, takie jak: redukcja jednostkowych kosztów produkcji, zakupów, dystrybucji lub transakcji przesuwają krzywą kosztów przedsiębiorstwa. W przypadku innowacji w obrębie procesów, które przyczyniają się do wzrostu wydajności, firma zyskuje przewagę kosztową nad 
swoimi konkurentami, co pozwala jej na zwiększenie marży przy najczęściej spotykanej cenie rynkowej lub - w zależności od elastyczności popytu - na zastosowanie niższej ceny przy wyższej od konkurencji marży dla zwiększenia udziału w rynku i wartości zysków (OECD, 2008). Innowacje organizacyjne mogą podnieść efektywność i jakość działań, tym samym zwiększając popyt lub obniżając koszty (Wallis, 2017). Innowacje mogą także zwiększać efektywność przedsiębiorstw, podnosząc ich zdolność innowacyjną, czyli zdolność do generowania nowych produktów lub procesów bądź też do pozyskiwania i tworzenia nowej wiedzy. Przykładowo, podniesienie wydajności procesów produkcyjnych może stworzyć szansę na opracowanie nowej serii produktów, a z kolei nowe praktyki organizacyjne mogą podnieść zdolność firmy do pozyskiwania i tworzenia nowej wiedzy, którą można wykorzystać do opracowywania kolejnych innowacji (OECD, 2008). Przedsiębiorstwa zaangażowane w tworzenie innowacji powinny mieć taką strategię innowacji, która gwarantowałaby pozytywny wpływ nie tylko na wynik procesu innowacyjnego, lecz także na wynik całej firmy (Scuotto i in., 2017). Innowacje oprócz bezpośredniego wpływu na efektywność funkcjonowania firmy budują także jej zdolność do wykorzystywania nowych technologii obecnych w maszynach i urządzeniach.

Inwestycje w innowacje są ważne dla firm i narodów, aby mogły konkurować o przyszłość i zapewnić przewagę konkurencyjną w coraz bardziej zglobalizowanym i niepewnym środowisku gospodarczym (Algieri, Aquino, Succurro 2018).

\section{Problem pomiaru efektów działalności innowacyjnej}

W literaturze przedmiotu funkcjonuje wiele definicji innowacji w ujęciu statycznym. Jednakże, oprócz takiego podejścia do innowacji, istnieje podejście dynamiczne, obejmujące cały proces, począwszy od tworzenia i projektowania aż po realizację i adaptację innowacji. Innowacja traktowana jako proces ma chronologiczny charakter, a zatem składa się z różnych etapów, pomiędzy którymi zachodzą interakcje, przy czym złożoność procesu innowacyjnego wzrasta wraz z przejściem z jednego etapu do kolejnego. Cechy procesu innowacyjnego, a głównie jego kompleksowość, powodują problemy z pomiarem działalności innowacyjnej (Kijek, 2011).

Zakres działalności innowacyjnej może być oceniany na rożnych poziomach (makro-, mezo-, mikro-) oraz w różnych sektorach gospodarki, innowacyjność całego systemu gospodarczego kraju jest bowiem rezultatem innowacyjności 
poszczególnych podmiotów, jakimi są przedsiębiorstwa przemysłowe i usługowe (Wodecka-Hyjek, 2013). Poziom innowacyjności polskich przedsiębiorstw i polskich regionów ma związek z poziomem rozwoju gospodarczego (Wich, 2017). Aby potwierdzić skuteczność tych działań podejmowanych na rzecz zwiększenia innowacyjności, konieczne jest wprowadzenie systemów pozwalających na pomiar ich efektów (Łada, Orchel-Szeląg, 2015).

Zainteresowanie pomiarem i oceną aktywności innowacyjnej i jej efektywności zauważyć można od relatywnie krótkiego czasu. Pierwsze takie badania pojawiły się w latach 80 . ubiegłego wieku i objęły swoim zasięgiem różne poziomy od przedsiębiorstw, poprzez regiony, po gospodarki krajowe i sytuację globalną (Karasek, 2012). Od tamtego momentu nieustannie wzrasta zainteresowanie tą tematyką, a jej celowość, metodologia i jakość uzyskiwanych wyników są przedmiotem ciągłych dyskusji (Bloch, 2005).

Do oceny efektywności aktywności innowacyjnej przedsiębiorstwa najczęściej wykorzystuje się metody stosowane powszechnie przy ocenie przedsięwzięć inwestycyjnych. W związku z tym procesy innowacyjne rozpatrywane są w charakterze decyzji inwestycyjnych, czyli w uproszczeniu jako nakłady, które trzeba ponieść, by uzyskać odroczone w czasie korzyści (Wrzosek, 2008). Konieczne zatem staje się ustalenie niezbędnych nakładów finansowych na wszystkich etapach procesu innowacyjnego oraz szans uzyskania planowanych efektów (Brzeziński, 2001). Jednakże powstają tu problemy związane z wykorzystaniem zasad rachunku ekonomicznego, a mianowicie należy zdefiniować i określić ryzyko oraz wstępnie ustalić konkretne skutki i efekty procesu innowacyjnego jeszcze przed przystąpieniem do jego realizacji. Jest to niezbędne dla dalszych ocen i analiz, a nawet bardzo często jest jedynym kryterium oceny końcowej efektywności innowacji. Nie uwzględnia się bowiem efektów dodatkowych, które powstają w trakcie wdrażania innowacji lub też w okresach późniejszych. Wynika to $\mathrm{z}$ brania pod uwagę jedynie pewnej ustalonej grupy oczekiwanych rezultatów jako wyniku doświadczeń lat ubiegłych oraz doraźnego naprawczego charakteru innowacji wdrażanych przez polskie przedsiębiorstwa. Częstym błędem jest też pomijanie w rachunku efektywności aspektów negatywnych oraz wyników i nakładów niespodziewanych, co w konsekwencji nie daje prawdziwego wyniku efektywności (Starczewska-Krzysztoszek, 2008). Ponadto brane pod uwagę nakłady i efekty muszą być wartościami wymiernymi i muszą być wyrażone w tych samych jednostkach (Białoń, 2010). Problem polega na tym, że nie wszystkie efekty, podobnie jak i nakłady, można ująć w kategoriach mierzalnych, a ponadto te mierzalne rezultaty innowacji pojawić się mogą dopiero w przyszłości jako wynik kompleksowej aktywności w zakresie innowacji danego 
przedsiębiorstwa. Uwzględnianie jedynie elementów wyrażonych w pieniądzu i eliminacja czynników niewymiernych znacząco zubaża obraz sytuacji i jest sprzeczne z kompleksowym ujmowaniem efektów z innowacji i maksymalizowaniem efektywności.

Kolejnym błędem popełnianym przez polskich przedsiębiorców jest ocena efektywności innowacji tylko na etapie podejmowania decyzji o wyborze wariantu przyszłej innowacji, a pomijanie lub ograniczanie oceny końcowej, czyli efektywności innowacji już po jej wdrożeniu. Ocena końcowa, jeśli jest, polega jedynie na zasadzie prostego porównania parametrów prognozowanych z rzeczywistymi. Ogranicza to wykorzystanie faktycznie uzyskanych efektów innowacji w działalności przedsiębiorstwa oraz skuteczne zarządzanie tą sferą w przyszłości (Innovation 2010).

Wzrost znaczenia innowacyjności dla sukcesów współczesnych przedsiębiorstw oraz sprawne ich zarządzanie powoduje rosnące zapotrzebowanie na narzędzia o charakterze analitycznym, które umożliwiają dokonanie pomiaru tego ważnego strategicznie aspektu ich działalności (Nawrocki, 2015; Juchniewicz i Grzybowska, 2010). Przegląd literatury przedmiotu wykazał, że gama narzędzi i mierników, która może być zastosowana do oceny poziomu innowacyjności krajów czy przedsiębiorstw, jest bardzo szeroka i różnorodna (Litwa, 2017). Zauważyć można także problem niejednorodnej skali pomiaru, np. oceny gospodarek krajów w statystykach Unii Europejskiej publikowane są corocznie, natomiast ocena poziomu innowacyjności przedsiębiorstw polskich dokonywana jest przez GUS w okresach trzyletnich (Wodecka-Hyjek, 2013). Odmienność metodologiczna w konstruowaniu mierników i analiz dotyczących innowacyjności również uniemożliwia dokonywanie porównań (Nowak, 2012).

\section{Efekty działalności innowacyjnej w Polsce i województwie lubelskim w latach 2016-2018}

Analizę efektów działalności innowacyjnej przeprowadzono, opierając się na takich wskaźnikach jak: udział przedsiębiorstw innowacyjnych w zakresie innowacji produktowych i procesów biznesowych w ogólnej liczbie przedsiębiorstw oraz udział przychodów netto ze sprzedaży produktów innowacyjnych, innowacyjnych tylko dla rynku i tylko dla przedsiębiorstwa w przychodach netto ze sprzedaży, określający stopień odnowienia produkcji (Szczepaniak, 2010). Działalność innowacyjną, czyli wdrożenie innowacji produktowych lub procesów biznesowych, bądź prowadzenie działalności innowacyjnej zanie- 
chanej lub niezakończonej w Polsce w latach 2016-2018 zadeklarowało 26,1\% przedsiębiorstw przemysłowych i $21,0 \%$ przedsiębiorstw usługowych (GUS, 2019). W $2018 \mathrm{r}$. innowacje wprowadziło $24,0 \%$ przedsiębiorstw przemysłowych i 19,6\% przedsiębiorstw usługowych (tabela 2). Zarówno innowacje produktowe, jak i innowacje procesów biznesowych częściej wprowadzały przedsiębiorstwa przemysłowe niż usługowe (GUS, 2019; szczecin.stat.gov.pl) (odpowiednio 16,8\% dla nowych lub ulepszonych produktów, 7,5\% dla nowych lub ulepszonych dla rynku produktów i 19,9\% dla nowych lub ulepszonych procesów biznesowych wobec odpowiednio 9,6\%, 4,2\% i 17,5\%).

Tabela 2. Odsetek przedsiębiorstw, które w latach 2016-2018 wprowadziły innowacje w Polsce

\begin{tabular}{|c|c|c|c|c|c|c|c|c|}
\hline \multirow{2}{*}{ Rok } & \multicolumn{3}{|c|}{ Przedsiębiorstwa z sektora usług } & \multicolumn{4}{|c|}{ Przedsiębiorstwa przemysłowe } \\
\cline { 2 - 9 } & Ogółem & $\begin{array}{c}\text { Nowe } \\
\text { lub } \\
\text { ulepszone } \\
\text { produkty }\end{array}$ & $\begin{array}{c}\text { Nowe lub } \\
\text { ulepszone } \\
\text { dla rynku } \\
\text { produkty }{ }^{1}\end{array}$ & $\begin{array}{c}\text { Nowe lub } \\
\text { ulepszone } \\
\text { procesy } \\
\text { biznesowe }\end{array}$ & Ogółem & $\begin{array}{c}\text { Nowe } \\
\text { lub } \\
\text { ulepszone } \\
\text { produkty }\end{array}$ & $\begin{array}{c}\text { Nowe lub } \\
\text { ulepszone } \\
\text { dla rynku } \\
\text { produkty }\end{array}$ & $\begin{array}{c}\text { Nowe lub } \\
\text { ulepszone } \\
\text { procesy } \\
\text { biznesowe }\end{array}$ \\
\cline { 2 - 9 } & {$[\%]$} & {$[\%]$} & {$[\%]$} & {$[\%]$} & {$[\%]$} & {$[\%]$} & {$[\%]$} & {$[\%]$} \\
\hline 2016 & 13,57 & 6,91 & 3,15 & 10,40 & 18,68 & 12,40 & 6,26 & 15,23 \\
\hline 2017 & 10,39 & 5,37 & 2,25 & 8,30 & 18,51 & 12,03 & 5,98 & 15,25 \\
\hline 2018 & 19,6 & 9,6 & 4,2 & 17,5 & 24,0 & 16,8 & 7,5 & 19,9 \\
\hline
\end{tabular}

Źródło: opracowanie własne na podstawie Banku Danych Lokalnych, https://bdl.stat.gov.pl.

W całym analizowanym okresie udział przemysłowych przedsiębiorstw innowacyjnych w ogólnej liczbie przedsiębiorstw był znacznie większy w województwie lubelskim (tabela 3; gdzie w 2018 r. wyniósł 30,7\% i odpowiednio w 2017 r. - 20,13\%, w 2016 r. - 22,47\%) niż średnio w Polsce (24\%, 18,51\%, 18,68\%). Natomiast odwrotna sytuacja wystąpiła w przypadku przedsiębiorstw usługowych, gdzie za wyjątkiem 2016 r. częściej innowacyjne były przedsiębiorstwa w Polsce (w 2018 r. - 19,6\%, w 2017 r. - 10,39\%) niż w województwie lubelskim (odpowiednio 19,1\%; 8,02\%). Jedynie w 2016 r. częściej innowacyjne były firmy z sektora usług w analizowanym województwie (23,33\%) niż w Polsce (13,57\%).

Analizując 2018 r., można stwierdzić, że aktywność innowacyjna przedsiębiorstw przemysłowych na Lubelszczyźnie była częściej podejmowana dla

1 O innowacji mówi się, że stanowi nowość dla danego rynku, jeśli firma jako pierwsza wprowadza daną innowację na swoim rynku. Rynek definiuje się w prosty sposób: jest to firma i jej konkurenci, przy czym rynek może obejmować region geograficzny lub linię produktów. Zakres terytorialny nowości dla rynku zależy więc od tego, jak dana firma sama postrzega swój rynek działania, co oznacza, że rynek może obejmować tak firmy krajowe, jak i zagraniczne. 
każdego rodzaju innowacji technologicznych (tj. produktowych i procesowych), natomiast przedsiębiorstwa usługowe z Lubelszczyzny wypadają lepiej na tle kraju tylko pod względem innowacji procesowych.

Tabela 3. Odsetek przedsiębiorstw, które w latach 2016-2018 wprowadziły innowacje w województwie lubelskim

\begin{tabular}{|c|c|c|c|c|c|c|c|c|}
\hline \multirow{2}{*}{ Rok } & \multicolumn{4}{|c|}{ Przedsiębiorstwa z sektora usług } & \multicolumn{4}{c|}{ Przedsiębiorstwa przemysłowe } \\
\cline { 2 - 9 } & Ogółem & $\begin{array}{c}\text { Nowe } \\
\text { lub } \\
\text { ulepszone } \\
\text { produkty }\end{array}$ & $\begin{array}{c}\text { Nowe lub } \\
\text { ulepszone } \\
\text { dla rynku } \\
\text { produkty }\end{array}$ & $\begin{array}{c}\text { Nowe lub } \\
\text { ulepszone } \\
\text { procesy } \\
\text { biznesowe }\end{array}$ & Ogółem & $\begin{array}{c}\text { Nowe } \\
\text { lub } \\
\text { ulepszone } \\
\text { produkty }\end{array}$ & $\begin{array}{c}\text { Nowe lub } \\
\text { ulepszone } \\
\text { dla rynku } \\
\text { produkty }\end{array}$ & $\begin{array}{c}\text { Nowe lub } \\
\text { ulepszone } \\
\text { procesy } \\
\text { biznesowe }\end{array}$ \\
\cline { 2 - 9 } & {$[\%]$} & {$[\%]$} & {$[\%]$} & {$[\%]$} & {$[\%]$} & {$[\%]$} & {$[\%]$} & {$[\%]$} \\
\hline 2016 & 23,33 & 12,07 & 1,12 & 12,88 & 22,47 & 14,61 & 5,57 & 17,53 \\
\hline 2017 & 8,02 & 3,92 & 2,67 & 6,21 & 20,13 & 14,57 & 4,70 & 14,00 \\
\hline 2018 & 19,1 & 4,2 & 2,7 & 17,9 & 30,7 & 22,2 & 9,3 & 24,5 \\
\hline
\end{tabular}

Źródło: opracowanie własne na podstawie Banku Danych Lokalnych, https://bdl.stat.gov.pl.

W latach 2016-2018 w grupie innowacji produktowych nowe lub znacząco ulepszone wyroby wprowadziło $15,2 \%$ przedsiębiorstw przemysłowych i $4,4 \%$ usługowych, natomiast nowe lub znacząco ulepszone usługi - 5,6\% przedsiębiorstw przemysłowych i 7,4\% usługowych (rysunek 1).

Rysunek 1. Odsetek przedsiębiorstw, które w latach 2016-2018 wprowadziły innowacje produktowe (dane w \%)

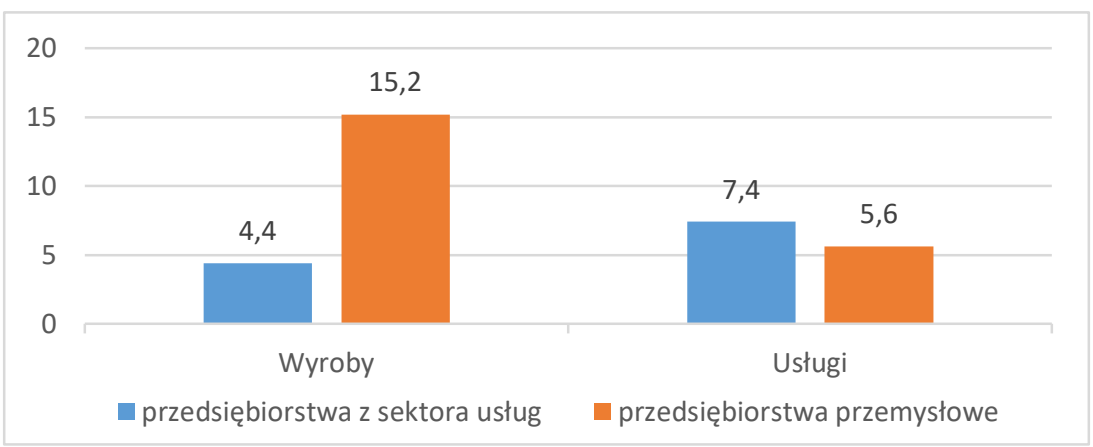

Źródło: opracowanie własne na podstawie Działalność innowacyjna przedsiębiorstw w Polsce w latach 20162018, GUS.

Innowacje procesów biznesowych w Polsce wdrożyło 19,9\% przedsiębiorstw przemysłowych oraz 17,5\% przedsiębiorstw usługowych (tabela 2). Korzystniej w tym względzie wypada województwo lubelskie, gdzie innowacje procesów 
biznesowych wdrożyło $24,5 \%$ przedsiębiorstw przemysłowych oraz $17,9 \%$ przedsiębiorstw usługowych (tabela 3).

Rysunek 2. Odsetek przedsiębiorstw, które w latach 2016-2018 wprowadziły innowacje procesów biznesowych (dane w \%)

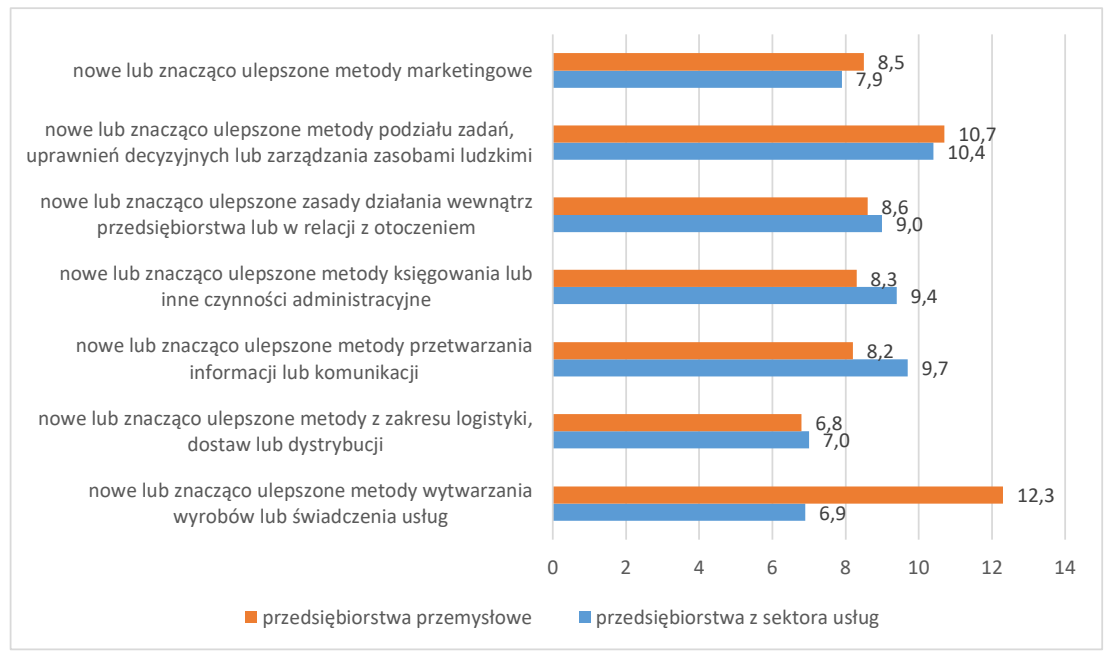

Źródło: opracowanie własne na podstawie Banku Danych Lokalnych, https://bdl.stat.gov.pl.

Przedsiębiorstwa przemysłowe najczęściej wprowadzały nowe lub znacząco ulepszone metody wytwarzania produktów lub świadczenia usług (12,3\%; rysunek 2), nowe lub znacząco ulepszone metody marketingowe (8,5\%) oraz nowe lub znacząco ulepszone metody podziału zadań, uprawnień decyzyjnych lub zarządzania zasobami ludzkimi (10,7\%), a firmy usługowe nowe lub znacząco ulepszone metody przetwarzania informacji lub komunikacji (9,7\%), nowe lub znacząco ulepszone metody księgowania lub inne czynności administracyjne $(9,4 \%)$, nowe lub znacząco ulepszone zasady działania wewnątrz przedsiębiorstwa lub w relacji z otoczeniem $(9,0 \%)$ oraz nowe lub ulepszone metody z zakresu logistyki, dostaw lub dystrybucji (7,0\%) (Dziemdziela, Krzyżanowska, 2020).

Szczególnie ważna dla korzystnego obrazu oceny innowacyjności przedsiębiorstw prowadzących działalność $\mathrm{w}$ województwie lubelskim jest ewidentnie wyższa niż średnio w Polsce aktywność małych przedsiębiorstw (zatrudniających 10-49 osób, tabela 4). W każdym analizowanym roku znacznie większy niż przeciętnie w Polsce odsetek z nich podjął trud działalności innowacyjnej w odniesieniu do każdego rodzaju innowacji technologicznych. Niestety można przypuszczać, że były to często innowacje imitacyjne, ważne dla rozwoju tychże podmiotów, ale mające mniejsze znaczenie dla rynku, gdyż w zakresie wdrażania 
innowacji produktowych nowych lub istotnie ulepszonych dla rynku województwo lubelskie wypada słabiej na tle kraju (Zakrzewska, 2014).

Tabela 4. Przedsiębiorstwa przemysłowe według rodzajów wprowadzonych innowacji i klas wielkości w Polsce i w województwie lubelskim w latach 2016-2018 (dane w \%)

\begin{tabular}{|c|c|c|c|c|c|c|c|}
\hline \multirow{2}{*}{$\begin{array}{c}\text { Rodzaj } \\
\text { innowacji }\end{array}$} & \multirow{2}{*}{$\begin{array}{c}\text { Wielkość } \\
\text { przedsiębiorstwa }\end{array}$} & \multicolumn{2}{|c|}{2016} & \multicolumn{2}{|c|}{2017} & \multicolumn{2}{|c|}{2018} \\
\hline & & Polska & Lubelskie & Polska & Lubelskie & Polska & Lubelskie \\
\hline \multirow{4}{*}{ Ogółem } & Ogółem & 18,68 & 22,47 & 18,51 & 20,13 & 24,0 & 30,7 \\
\hline & Zatrudniające 10-49 & 11,24 & 15,11 & 11,32 & 12,14 & 17,0 & 24,4 \\
\hline & Zatrudniajace 50-249 & 32,96 & 36,99 & 32,26 & 33,60 & 37,2 & 42,1 \\
\hline & $\begin{array}{l}\text { Zatrudniające } 250 \\
\text { i więcej }\end{array}$ & 58,74 & 64,81 & 59,34 & 61,67 & 62,3 & 72,6 \\
\hline \multirow{4}{*}{$\begin{array}{l}\text { Nowe lub } \\
\text { ulepszone } \\
\text { produkty }\end{array}$} & Ogółem & 12,40 & 14,61 & 12,03 & 14,57 & 16,8 & 22,2 \\
\hline & Zatrudniające 10-49 & 7,09 & 9,70 & 6,79 & 10,64 & 11,5 & 17,9 \\
\hline & Zatrudniające 50-249 & 21,90 & 23,58 & 21,30 & 18,40 & 26,2 & 29,6 \\
\hline & $\begin{array}{l}\text { Zatrudniające } 250 \\
\text { i więcej }\end{array}$ & 44,16 & 46,30 & 45,13 & 46,67 & 48,0 & 50,0 \\
\hline \multirow{4}{*}{$\begin{array}{l}\text { Nowe lub } \\
\text { ulepszone } \\
\text { dla rynku } \\
\text { produkty }\end{array}$} & Ogółem & 6,26 & 5,57 & 5,98 & 4,70 & 7,5 & 9,3 \\
\hline & Zatrudniające 10-49 & 3,42 & 3,27 & 3,24 & 1,91 & 4,9 & 8,5 \\
\hline & Zatrudniające 50-249 & 10,94 & 8,94 & 10,50 & 7,60 & 11,6 & 8,5 \\
\hline & $\begin{array}{l}\text { Zatrudniające } 250 \\
\text { i więcej }\end{array}$ & 25,03 & 24,07 & 24,58 & 26,67 & 23,9 & 22,6 \\
\hline \multirow{4}{*}{$\begin{array}{l}\text { Nowe lub } \\
\text { ulepszone } \\
\text { procesy } \\
\text { biznesowe }\end{array}$} & Ogółem & 15,23 & 17,53 & 15,25 & 14,00 & 19,9 & 24,5 \\
\hline & Zatrudniające 10-49 & 9,10 & 10,83 & 9,00 & 5,32 & 13,4 & 18,5 \\
\hline & Zatrudniające 50-249 & 26,39 & 30,89 & 26,70 & 29,20 & 31,9 & 36,0 \\
\hline & $\begin{array}{l}\text { Zatrudniające } 250 \\
\text { i więcej }\end{array}$ & 51,00 & 57,41 & 53,00 & 56,67 & 56,9 & 59,7 \\
\hline
\end{tabular}

Źródło: opracowanie własne na podstawie Banku Danych Lokalnych, https://bdl.stat.gov.pl.

W 2018 r. znacznie większy niż średnio w Polsce odsetek wszystkich przedsiębiorstw, zarówno małych, średnich, jak i dużych z województwa lubelskiego prowadził działalność innowacyjną - w odniesieniu do wszystkich rodzajów innowacji. Ważnym zjawiskiem był również wzrost odsetka innowacyjnych przedsiębiorstw przemysłowych w $2018 \mathrm{r}$. w stosunku do lat poprzednich, zarówno w Polsce, jak i w województwie lubelskim, w każdej klasie wielkości i w każdym rodzaju wdrożonych innowacji.

Niska rynkowa atrakcyjność innowacji wprowadzanych przez przedsiębiorstwa z województwa lubelskiego znalazła odzwierciedlenie w niskim udziale przychodów netto ze sprzedaży produktów innowacyjnych w produkcji sprzedanej 
przemysłu, który był w badanym województwie prawie połowę mniejszy niż średnia dla kraju (tabela 5). W 2018 r. udział przychodów ze sprzedaży produktów nowych lub znacząco ulepszonych, wprowadzonych na rynek w przychodach ogółem w firmach przemysłowych wyniósł 9,1\%, w usługowych - 3,2\% (GUS, 2019; szczecin.stat.gov.pl), natomiast w przedsiębiorstwach przemysłowych na Lubelszczyźnie wyniósł 4,9\%.

Tabela 5. Udział przychodów netto ze sprzedaży produktów innowacyjnych w przedsiębiorstwach przemysłowych województwa lubelskiego i Polski w latach 2016-2018 (dane $\mathrm{w} \%$ )

\begin{tabular}{|l|c|c|c|c|c|c|}
\hline \multirow{2}{*}{ Wyszczególnienie } & \multicolumn{2}{|c|}{2016} & \multicolumn{2}{c|}{2017} & \multicolumn{2}{c|}{2018} \\
\cline { 2 - 7 } & Polska & Lubelskie & Polska & Lubelskie & Polska & Lubelskie \\
\hline $\begin{array}{l}\text { Udział przychodów netto ze } \\
\text { sprzedaży produktów innowacyj- } \\
\text { nych w przychodach ze sprzedaży } \\
\text { ogółem }\end{array}$ & 8,12 & 6,18 & 7,08 & 3,81 & 9,1 & 4,9 \\
\hline $\begin{array}{l}\text { Udział przychodów netto ze sprze- } \\
\text { daży produktów innowacyjnych } \\
\text { dla rynku w przychodach netto ze } \\
\text { sprzedaży ogółem }\end{array}$ & 3,95 & 3,91 & 3,44 & 1,82 & 3,2 & 2,1 \\
\hline $\begin{array}{l}\text { Udział przychodów netto ze } \\
\text { sprzedaży produktów innowacyj- } \\
\text { nych tylko dla przedsiębiorstwa } \\
\text { w przychodach netto ze sprzedaży } \\
\text { ogółem }\end{array}$ & 4,17 & 2,27 & 3,64 & 1,99 & 5,9 & 2,8 \\
\hline
\end{tabular}

Źródło: opracowanie własne na podstawie Banku Danych Lokalnych, https://bdl.stat.gov.pl.

Udział przychodów netto ze sprzedaży produktów innowacyjnych w firmach przemysłowych województwa lubelskiego był w każdym analizowanym roku niższy niż w Polsce, zarówno dla produktów innowacyjnych ogółem, nowych dla rynku, jak i będących nowością tylko dla przedsiębiorstwa.

Największy udział tych przychodów, zarówno w polskich przedsiębiorstwach przemysłowych, jak i usługowych odnotowano w podmiotach o liczbie pracujących 250 osób i więcej (odpowiednio 11,3\% i 5,1\%). Wyróżnia się przychody ze sprzedaży produktów nowych lub znacząco ulepszonych dla rynku, na którym działa przedsiębiorstwo, oraz tylko dla przedsiębiorstwa. W 2018 r. udział przychodów ze sprzedaży produktów nowych lub znacząco ulepszonych dla rynku w przychodach ze sprzedaży produktów innowacyjnych zarówno w przemyśle, jak i w usługach wyniósł 34,9\% (GUS, 2019; szczecin.stat.gov.pl).

Negatywnym zjawiskiem jest to, że udział przychodów netto ze sprzedaży produktów innowacyjnych w przychodach netto ze sprzedaży ogółem dla przed- 
siębiorstw w województwie lubelskim (4,9\%) był w 2018 r. jednym z najniższych wskaźników dla całego kraju, znalazł się na trzecim miejscu od końca, zaraz po województwie zachodniopomorskim (3,2\%) i świętokrzyskim (4,5\%) (rysunek 3). Najwyższą wartość wskaźnika osiągnęły podmioty w województwie lubuskim (12,8\%), która jest ponad 2,5 razy wyższa niż dla firm z województwa lubelskiego. Na drugim miejscu pod względem wielkości wskaźnika znalazło się województwo małopolskie (12,1\%), na kolejnych mazowieckie (10,3\%) i wielkopolskie (10\%). Pozostałe województwa osiągnęły wartość poniżej $10 \%$.

Rysunek 3. Udział przychodów netto ze sprzedaży produktów innowacyjnych w przychodach netto ze sprzedaży ogółem w podmiotach przemysłowych w poszczególnych województwach w Polsce w 2018 r. (dane w \%)

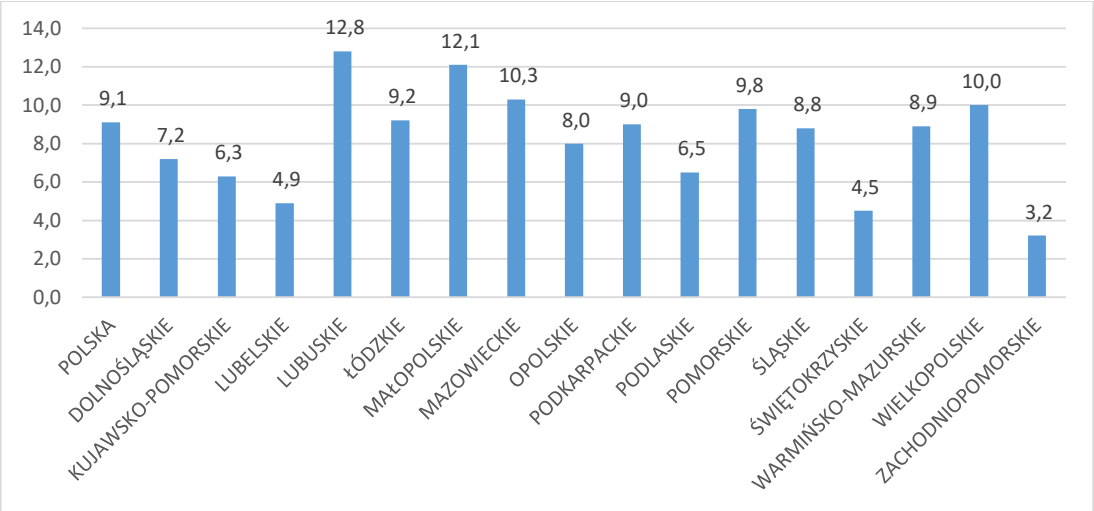

Źródło: opracowanie własne na podstawie Banku Danych Lokalnych, https://bdl.stat.gov.pl.

\section{Zakończenie}

Wdrażanie innowacji stanowi nieodłączny element podnoszenia konkurencyjności przedsiębiorstw, regionów, jak i całego kraju. Złożoność tego procesu, jego rozciągnięcie $\mathrm{w}$ czasie, niejednokrotnie wysokie ryzyko z nim związane oraz zakres aktywności innowacyjnej powodują problemy z pomiarem tej sfery funkcjonowania przedsiębiorstw i jej efektów. Innowacje dają m.in. szansę zwiększania skali produkcji i sprzedaży, obniżania kosztów czy poprawy jakości wytwarzanych dóbr i usług (Litwa, 2017). Z tego powodu bardzo istotny jest wartościowy pomiar efektów aktywności innowacyjnej i zastosowanie w tym celu właściwych metod. W 2018 r. w porównaniu z 2016 r. nastąpił wzrost odsetka innowacyjnych przedsiębiorstw przemysłowych i usługowych zarówno w Polsce, jak i na Lubelszczyźnie, co należy uznać za zjawisko pozytywne. Natomiast nie- 
korzystne w tych latach jest zmniejszenie udziału przychodów netto ze sprzedaży produktów innowacyjnych w przychodach ze sprzedaży ogółem. Największy odsetek przedsiębiorstw aktywnych innowacyjnie występuje wśród dużych podmiotów, toteż istnieje konieczność pobudzania aktywności innowacyjnej wśród mikro, małych i średnich przedsiębiorstw.

\section{Bibliografia}

\section{Literatura}

Algieri, B., Aquino, A., Succurro, M. (2018). The Impact Of Capital Structure On Firms' Innovative Performance. 59.Ma Riunione Scientifica Annuale (Rsa) Sie Società Italiana Degli Economisti Bologna, 25-27 Ottobre 2018, 1-12.

Białoń, L. (red.). (2010). Zarządzanie działalnością innowacyjna. Warszawa: Placet.

Bloch, C. (2005). Innovation measurement: present and future challenges. Working paper from The Danish Centre for Studies in Research and Research Policy, 6.

Brzeziński, M. (red). (2001). Zarządzanie innowacjami technicznymi i organizacyjnymi. Warszawa: Difin.

Chabiera, S. (2013). Ocena znaczenia innowacji w rozwoju polskich mikro i małych przedsiębiorstw. W: Przewaga konkurencyjna dzisiaj i jutro (s. 67-90). Warszawa: PRET S. A.

Dziemdziela, P., Krzyżanowska, K. (2020). Działalność innowacyjna małych i średnich przedsiębiorstw w Polsce. Turystyka i Rozwój Regionalny, 14, 89-100.

Juchniewicz, M., Grzybowska, B. (2010). Innowacyjność mikroprzedsiębiorstw w Polsce. Warszawa: PARP.

Karasek, A. (2012). Wybrane problemy efektywności przedsięwzięć innowacyjnych przedsiębiorstwa. Zarzadzanie i Finanse, 10(1), 305-314

Karmańska, A. (red.). (2007). Zarządzanie kosztami jakości, logistyki, innowacji, ochrony środowiska a rachunkowość finansowa. Warszawa: Difin.

Kijek, T. (2011). Ocena efektywności działalności innowacyjnej przedsiębiorstw. Ekonomika i Organizacja Przedsiębiorstwa, 1, 19-25.

Litwa, P. (2017). Pomiar stopnia innowacyjności przedsiębiorstwa przy wykorzystaniu Balanced Scorecard. Studia i Prace WNEIZ US, 48(3), 151-162.

Łada, M., Orchel-Szeląg, A. (2015). Pomiar efektów projektów innowacyjnych - studium przypadku KIC Innoenergy. Studia Ekonomiczne, Zeszyty Naukowe Uniwersytetu Ekonomicznego w Katowicach, 244, 120-129.

Matras-Bolibok, A. (2009). Efektywność działalności innowacyjnej przedsiębiorstw przemysłu spożywczego w Polsce. Roczniki Naukowe Stowarzyszenia Ekonomistów Rolnictwa i Agrobiznesu, 11(1), 262-267. 
Nawrocki, T. (2015). Problematyka pomiaru i oceny innowacyjności przedsiębiorstw. Zeszyty Naukowe Politechniki Śląskiej, Seria: Organizacja i Zarządzanie, 79, 217-226.

Nowak, P. (2012). Pomiar innowacyjności polskiej gospodarki na tle krajów UE. Prace Komisji Geografii Przemystu, 19, 142-152.

OECD. (2008). Oslo Manual. Zasady gromadzenia i interpretacji danych dotyczacych innowacji. Warszawa: MNiSW.

Scuotto, V., Del Giudice, M., Bresciani, S., Meissner, D. (2017). Knowledge-driven preferences in informal inbound open innovation models. An explorative view small to medium enterprises. Journal of Knowledge Management, 21(3), 1-12.

Stanisławski, R. (2017). Open innovation a rozwój innowacyjny mikro, małych i średnich przedsiębiorstw. Łódź: Wydawnictwo Politechniki Łódzkiej.

Starczewska-Krzysztoszek, M. (2008). Ranking najbardziej innowacyjnych firm w Polsce. Warszawa: PARP.

Szczepaniak, I. (2016). Ekonomiczna ocena innowacyjności przedsiębiorstw przemysłu spożywczego. Przemysł Spożywczy, 70(2), 2-6.

Wich, U. (2017). Innowacyjność Polski w ocenie Unii Europejskiej i z perspektywy regionów. Annales Universitatis Mariae Curie-Skłodowska, 1, 101-111.

Wallis, A. (2017). Innowacyjność narzędziem kształtowania przewagi konkurencyjnej przedsiębiorstwa XXI wieku. Zeszyty Naukowe Wydziału Nauk Ekonomicznych, 1(20), 311-325.

Wodecka-Hyjek, A. (2013). Wybrane narzędzia pomiaru innowacyjności. Zeszyty Naukowe Uniwersytet Ekonomiczny w Krakowie, Seria Zarzadzanie, 922, 63-82.

Wrzosek, S. (red.). (2008). Ocena efektywności inwestycji. Wrocław: Wydawnictwo UE. Zakrzewska, A. (2014). Efektywność nakładów ponoszonych na działalność innowacyjną w przedsiębiorstwach przemysłu spożywczego w Polsce. Stowarzyszenie Ekonomistów Rolnictwa i Agrobiznesu, Roczniki Naukowe, 16(5), 238-243.

\section{Źródła online}

Bank Danych Lokalnych. (b.d.). Pobrano z https://bdl.stat.gov.pl. (16.08.2020)

GUS. Słownik pojęć. (b.d.). Pobrano z https://stat.gov.pl/metainformacje/slownik-pojec/ pojecia-stosowane-w-statystyce-publicznej/4253,pojecie.html (30.10.2020)

GUS. (2019). Działalność innowacyjna przedsiębiorstw w Polsce w latach 2016-2018, GUS, Informacje sygnalne, 28.10.2019. Pobrano $\mathrm{z}$ https://stat.gov.pl/obszary-tematyczne/ nauka-i-technika-spoleczenstwo-informacyjne/nauka-i-technika/dzialalnosc-innowacyjna-przedsiebiorstw-w-latach-2016-2018,2,17.html (15.10.2020).

Innovation. (2010). A return to Prominence - and theEmergence of a New World Order, $B C G$. Pobrano z http://www.slideshare.net/fred.zimny/boston-consulting-group- 
-innovation-2010-a-return-to-prominence-and-the-emergence-of-a-new-world-order. (16.10.2020).

www.szczecin.stat.gov.pl

\section{Streszczenie}

Innowacyjność przedsiębiorstwa jest kluczowa dla jego przetrwania i konstruktywnego rozwoju. Dlatego też istotny jest jej pomiar oraz pomiar efektów tej aktywności i zastosowanie w tym celu odpowiednich metod. Celem artykułu jest prezentacja najważniejszych problemów związanych z tym pomiarem, jak również próba przedstawienia i oceny efektów działalności innowacyjnej przedsiębiorstw z Polski oraz z województwa lubelskiego w latach 2016-2018 na podstawie wskaźników, takich jak: udział przedsiębiorstw innowacyjnych w zakresie innowacji produktowych i procesów biznesowych w ogólnej liczbie przedsiębiorstw oraz udział przychodów netto ze sprzedaży produktów innowacyjnych, innowacyjnych tylko dla rynku i tylko dla przedsiębiorstwa w przychodach netto ze sprzedaży, określający stopień odnowienia produkcji.

SŁowA KLUCzowe: innowacje, działalność innowacyjna, efekty innowacji, pomiar działalności innowacyjnej.

\section{Summary}

Business innovation is crucial for its survival and constructive development. Therefore, it is very important to measure it and measure the results of this activity as well as use appropriate methods for this purpose. The aim of this article is to present the main problems related to this measurement as well as an attempt to show and evaluate the results of innovative activities of companies from Poland and the Lubelskie Voivodeship in 2015-2018 based on indicators such as: the share of funds in the field of product innovation and training to support enterprises as well as the share of net sales from the sale of products, which are only innovative for the market and only for the company in net sales revenue, which indicates the degree of renewal of production.

KEYwORDs: innovations, innovative activity, the effects of innovation, measurement of innovative activity.

\section{Nota o autorze}

Beata Podstawka - mgr, asystent, Katedra Mikroekonomii i Ekonomii Stosowanej, Wydział Ekonomiczny, Instytut Ekonomii i Finansów, Uniwersytet Marii Curie-Skłodowskiej w Lublinie; główne obszary działalności naukowej: ekonomia, finanse, zarządzanie finansami przedsiębiorstw, analiza finansowa, innowacje; e-mail: beata.slowik@poczta.umcs.lublin.pl; ORCID: 0000-0001-5151-4114. 